\title{
Do Female Enrolment Rates Cause Economic Growth in Pakistan?
}

\author{
Khalid Zaman \\ Assistant Professor, Department of Management Sciences, COMSATS Institute of Information Technology \\ Abbottabad, Pakistan \\ Tel: 92-334-898-2744Ｅ-mail: khalidzaman@ciit.net.pk \\ Muhammad Mushtaq Khan \\ Head of the Department, Management Sciences, COMSATS Institute of Information Technology \\ Abbottabad, Pakistan \\ Tel: 92-992-383-5916Ｅ-mail: khanmm@ciit.net.pk \\ Mehboob Ahmad \\ Professor, Department of Management Sciences, FUIEMS, Foundation University, New Lalazar \\ Rawalpindi Cantt, Pakistan
}

Tel: 92-333-520-2377Ｅ-mail: mmehboobahmad@gmail.com

Waseem Ikram

Assistant Professor, Department of Management Sciences, COMSATS Institute of Information Technology

Abbottabad, Pakistan

Te: 92-321-980-1301Ｅ-mail: drwaseem@ciit.net.pk

\begin{abstract}
There has been much discussion on the relationship between education and economic growth. A few studies have examined the increasing trend of female enrolment in educational institutions and economic growth. The objective of this paper is to empirically investigate four alternatives but equally plausible hypotheses. These are: i) GDP cause female enrolment proxies (the conventional view), ii) Female enrolment proxies cause GDP, iii) There is a bi-directional causality between the two variables and iv) Both variables are causality independent. In order to find the relationship between the two variables set, a time series Co-integration and Granger Causality Tests have been employed separately. Secondary data pertaining to Pakistan from 1966 - 2008 has been used for analysis. The empirical results moderately support the conventional view that GDP has significant long-run casual effect on the female enrolment proxies in Pakistan. The present study supports the unidirectional causality relationship between the GDP and female enrolment in the specific context of Pakistan.
\end{abstract}

Keywords: Female enrolment, Economic growth, Cointegration, Granger causality, Pakistan

\section{Introduction}

The Millennium Development Goals that emerged from the UN Millennium Declaration of September 2000 are specific measurable targets, including the one for reducing the extreme poverty that still grips more than 1 billion of the world's people by 2015. Central to this promise are the MDGs related to educational outcomes: (1) Ensure that all children complete primary education by 2015. (2) Eliminate gender disparities in primary and secondary education. By 2006, most countries have already fallen well behind the necessary targets to meet these goals (Millennium Development Goal, 2006).

Human capital is considered as an important determinant of economic growth which is effective vehicle for reducing income inequality and absolute poverty (World Bank, 2008). According to Barnet (1990), human capital investment in the form of higher education is recognized as capital investment, while, Ozsoy (2008) says that human capital is an engine of development for the new world economy. According to Abbas (undated), 
education was considered as a tool for human development in the past but now it is considered as a tool of development in broad meanings such as economic, social and also human resource development.

The number of studies has been examined the role of human capital as an important determinant of economic growth (e.g., Romer, 1986; Lucas, 1988). This is supported by number of empirical studies that human capital (such as years of schooling, school enrolment rates, or literacy rates) have statistically significant and positive effects on economic growth (e.g., Romer, 1990; Barro, 1991; Barro and Sala-i-Martin, 1992; Mankiw, Romer and Weil, 1992; Barro and Lee, 1994). Few studies considered, variables reflecting health status (such as life expectancy) are also significant in cross-country growth regressions (e.g., Wheeler, 1980; Barro and Lee, 1994; Knowles and Owen, 1995, 1997).

Most of the cross-country empirical literature on the effect of human capital on growth is "gender-neutral". It usually focuses on levels of education (or health) averaged over the whole (working-age) population. However, female and male education affects growth in quite different ways. Female education along with male education can improve productivity directly when better-educated females participate in the paid workforce and contribute to conventionally measured output. However, female participation rates are generally lower than for males and vary widely across countries. Conventional measures of output, which ignore women's role in non-market home production activities, have long been recognized as understating women's economic contribution relative to men. There is a growing literature, especially in the context of developing countries, female education produces social gains by reducing fertility, infant and child mortality, improving family and child health, increasing life expectancy, and raising the educational attainment of children (e.g., Schultz, 1988; Behrman and Deolalikar, 1988; Bellew et al, 1992; Subbarao and Raney, 1995).

Hence, even if female participation rates are lower than for males, the effects of improved female education on general levels of education, health status and fertility can boost measured productivity growth indirectly. Schultz (1995) concludes that female school enrolment has an apparently greater positive impact on economic growth than male school enrolment. However, he does not control for the influence of any of the other variables generally accepted as affecting growth. Hill and King (1993) suggest that both the level of female education and the gap between the levels of male and female education are significant determinants of economic growth. They imply that failure to improve female education to the same (or higher) average level as that of males acts as a brake on development. This contrasts with the results of one of the most influential recent empirical growth studies (Barro and Lee, 1994). Barro and Lee (hereafter BL) argued that, whereas growth is positively related to male schooling, it is negatively related to female schooling.

Stokey (1994) gives an explanation of this puzzling result in response to BL's paper. She argues that the female education variable acts as a dummy variable for geographic regions or ethnic groups that educate women differently from men, especially the (fast-growing) East Asian "Tigers" (Hong Kong, Korea, Singapore and Taiwan). She suggests that the female education variable should be dropped from the BL growth equations and that, given the high correlation between the female and male education variables. This is itself of interest given that, some studies have started questioning the role and significance of educational attainment variables in growth equations, e.g., Pritchett (1996) and Bils and Klenow (1998). Also, Knowles and Owen (1995, 1997) argue that education is not statistically significant in a range of models that include life expectancy and base-period output per worker.

In a Pakistan's perspective, United Nations, State Bank of Pakistan Reports and Economic Survey of Pakistan has given the light on Pakistan's' educational scenario. According to Human Development report (2005),

"The rank of Pakistan is $135^{\text {th }}$ among 177 countries indicating low life expectancy at birth, low educational attainment and low income. The report also indicates the adult literacy rate of age (15 years and above) as $35.2 \%$ of female as compared to $61.7 \%$ of male. In the same report, the Gender related development index (GDI) rank of Pakistan is $107^{\text {th }}$ among 177 countries. This explains as how the Human Development gap has been further aggravated by substantial gender disparities".

In annual report of State Bank of Pakistan (2004-05) discussed the current situation of education in Pakistan. The report states that,

"Unfortunately, Pakistan's track record in literacy and education has not been satisfactory. The education system in the country is characterized by highly illiteracy rate, low gross and net enrolment at all level of education, high dropout rates from schools, a wide disparity at gender and regional level, and a poor quality of education" (Annual report of State Bank of Pakistan, 2004-05).

In this connection, Economic Survey of Pakistan, 2009-10 states that, 
"The overall literacy rate (age 10 years and above) is $57 \%$ (69\% for male and $45 \%$ for female) compared to $56 \%$ (69\% for male and $44 \%$ for female) for $2007-08$. The data shows that literacy remains higher in urban areas (74\%) than in rural areas (48\%), and is more prevalent for men (69\%) compared to women (45\%). However, it is evident from the data that overall female literacy is rising over time, but progress is uneven across the provinces. Similarly, the overall school attendance, as measured by the Net Enrolment Rate (NER), for 2008-09 was 57\% as compared to 55\% in 2007-08. Nationally, the Gross Enrolment Rate (GER), sometimes referred to as the participation rate, which is the number of children attending primary school (irrespective of age) divided by the number of children who ought to be attending, in case of both male and female saw no change and remained at $91 \%$ between $2007-08$ and 2008-09".

The above discussion shows the strong connection between female education and economic growth. In this paper an analysis has been carried out to find a statistical relationship between female enrolment proxies and economic growth in Pakistan using secondary data from 1966 to 2009. The objectives of this paper are to empirically investigate:

- Whether the statistical relationship between the female enrolment and the economic growth in Pakistan is unidirectional (female education affect/cause economic growth or growth affect / cause female education );

- Whether the statistical relationship between the female enrolment and the economic growth in Pakistan is bi-directional (female education affect/cause growth and growth affect / cause female education );

- The two variables (female education and growth) do not influence each other (causality independent).

The paper is organized as follows: after introduction which is provided in Section 1 above, data sources and methodological framework is explained in Section 2. The estimation and interpretation of results is mentioned in Section 3. Section 4 concludes the paper.

\section{Data Source and Methodological Frame Work}

The study uses annual observations for the period of 1966-2008. The data is obtained from various issues of Economic Survey of Pakistan, International Financial Statistics, and World Bank Development Indicators data base (2009). To examine the impact of female enrolment in educational institutes on economic growth, the present study used seven different proxies i.e., female primary school enrolment (FPSE), female middle school enrolment (FMSE), female high school enrolment (FHSE), female secondary vocational enrolment (FSVE), female arts \& science colleges enrolment (FASCE), female professional colleges enrolment (FPCE) and female universities level enrolment (FULE)] as a dependent variables separately regress on economic growth (GDP) which covering the period of 1966-2008. We have estimated a simple non-linear growth-enrolment model which has been specified as follows:

$$
\begin{aligned}
& \log (F P S E)=\alpha_{1}+\alpha_{2} \log (G D P)+\mu \\
& \log (F M S E)=\beta+B_{2} \log (G D P)+\mu \\
& \log (F H S E)=\gamma_{1}+\gamma_{2} \log (G D P)+\mu \\
& \log (F S V E)=\chi_{1}+\chi_{2} \log (G D P)+\mu \\
& \log (F A S C E)=\delta_{1}+\delta_{2} \log (G D P)+\mu \\
& \log (F P C E)=\phi_{1}+\phi_{2} \log (G D P)+\mu \\
& \log (F U L E)=\kappa_{1}+\kappa_{2} \log (G D P)+\mu
\end{aligned}
$$

Where,

i. FPSE represents female primary school enrolment ('000 in numbers),

ii. FMSE represents female middle school enrolment ('000 in numbers),

iii. FHSE represents female high school enrolment ('000 in numbers),

iv. FSVE represents female secondary vocational enrolment in numbers, 
v. FASCE represents female arts \& science colleges enrolment in numbers,

vi. FPCE represents female professional colleges enrolment in numbers,

vii. FULE represents female universities level enrolment in numbers and

viii. GDP represents Gross Domestic Product at constant Prices at Pak Rs. in million

\subsection{Econometric Procedure}

This paper reviews the impact of economic growth on female enrolment proxies are examined in the following manners:

- By examining whether a time series have a unit root test; an Augmented Dickey-Fuller (ADF) unit root test has been used.

- By finding the long run relationship among the variable, Engle and Granger Cointegration test has been applied.

- When the variables are found cointegrated, an Error -Correction Model (ECM) has been applied to determine the short run dynamics of the system.

\subsubsection{Cointegration Test}

The concept of Cointegration was first introduced by Granger (1981) and elaborated further by Engle \& Granger (1987), Phillips \& Ouliaris (1990) and Johansen (1991), among others. Engle \& Granger Cointegration test requires that

- Time-series, say $Y_{t}$ and $X_{t}$, are non-stationary in levels but stationary in first differences i.e., $Y_{t} \sim I(1)$ and $X_{t}^{t} \sim I(1)$

- There exist $a \wedge$ linear combination between these two series that is stationary at levels i.e., $v_{i t}\left(=Y_{t}-\alpha-\beta X_{t}\right) \sim I(0)$.

Thus, the first step for Cointegration is to test whether each of the series is stationary or not. If they both are stationary say at first difference i.e. they are $I(1)$, then we may go to the second step to verify the long run relationship between them.

Augmented Dickey Fuller (ADF) test is usually applied to test stationarity. It tests the null hypothesis that a series $\left(Y_{t}\right)$ is non-stationary by calculating a t-statistics for $\beta=0$ in the following equation:

$\Delta Y_{t}=\alpha+\beta Y_{t-1}+\gamma_{t}+\sum_{k} \delta_{k} \Delta Y_{t-k}+\varepsilon_{t}$

Where $\mathrm{k}=2,3, \ldots, \mathrm{n}$. Whité ${ }^{2} \alpha, \beta, \gamma$ and $\delta$ are the parameters to be estimated and $\varepsilon_{t}$ is white noise error term.

If the value of the ADF statistic is less than the critical value at the conventional significance level (usually the $5 \%$ significance level) then the series $\left(Y_{t}\right)$ is said to stationary and vice versa. If $Y_{t}$ is found to be non-stationary then it should be determined whether $Y_{t}$ is stationary at first differences $\Delta Y_{t} \sim I(0)$ by repeating the above procedure. If the first difference of the series is stationary then the series $\left(Y_{t}\right)$ may be concluded as integrated of order one i.e. $Y_{t} \sim \mathrm{I}(1)$.

\subsubsection{Error Correction Model (ECM)}

If time series are $I(1)$, then regressions could be run in their first differences. However, by taking first differences, the long-run relationship will be lost that is stored in the data. This implies to use variables in levels as well. Advantage of the Error Correction Model (ECM) is that it incorporates variables both in their levels and first differences. By doing this, ECM captures the short-run disequilibrium situations as well as the long-run equilibrium adjustments between variables. ECM term having negative sign and value between " 0 and 1 " indicates convergence of model towards long run equilibrium and shows how much percentage adjustment takes place every year.

\subsubsection{Granger Causality Test}

If a pair of series is cointegrated then there must be Granger-causality in at least one direction, which reflects the direction of influence between series. Theoretically, if the current or lagged terms of a time series variables, say $X_{t}$, determine another time-series variable, say $Y_{t}$, then there exists a Granger-causality relationship between $X_{t}{ }_{t}$ and $Y_{t}$, in which $Y_{t}$ is granger caused by $X_{t}^{t}$. 


\section{Estimation and Interpretation of Results}

Economic time-series data are often found to be non-stationary, containing a unit root. Ordinary Least Squares (OLS) estimates are efficient if variables included in the model are stationary of the same order. Therefore, first we need to check the stationarity of all variables i.e. FPSE, FMSE, FHSE, FSVE, FASCE, FPCE, FULE and GDP used in the study. For this purpose we apply Augmented Dickey-Fuller (ADF) test. Table 1 gives the results of ADF tests.

Based on the ADF tests, all variables appear to be non-stationary at levels but stationary at first difference. Thus, we may conclude that these variables are integrated of order one i.e. $I$ (1). The Figure below shows the plots of female enrolment proxies and GDP in first difference forms, which sets the analytical framework as regarding the long-term relationship of enrolment and nominal growth.

Figure 1 shows the plots of female enrolment proxies and GDP in first difference forms, which sets the analytical framework as regarding the long-term relationship of enrolment and nominal growth. The cointegration test between female enrolment variables and GDP are carried out separately as mentioned below:

\subsection{Cointegration Test for FPSE and GDP}

Cointegration test for the first female enrolment variable (FPSE) and economic growth (GDP) would help us to clarify if relationship between these two variables exists. Results of regression and ADF test for the residual are presented in Table 2 and Table 3 respectively. The finding reveals that the residual is stationary at level i.e., it is integrated of order zero. This authenticates our intention that FPSE and GDP are indeed cointegrated that is a long run relationship between them holds. In order to ensure stability of long run relationship between FPSE and GDP, an Error Correction Model (ECM) has been used. The results are presented in Table 4.

The finding reveals that the short run effect and the long run adjustment impact of FPSE and GDP is significant at $5 \%$ level. The adjustment parameter $(p)$ appears with negative value signifying the long run convergence. The ECM estimation reveals that $14.4 \%$ of the disequilibrium in FPSE produced by GDP would be adjusted in every year. The conclusion is that there is a stable long run relationship between FPSE and GDP.

To confirm the causal relationship between the FPSE and GDP, a Granger-Causality test has been applied using lag length up to four periods. The following four hypotheses are tested.

1) FPSE Granger causes GDP

2) GDP Grange causes FPSE

3) Causality runs in both directions

4) FPSE and GDP are independent.

The results are provided in Table 5. It shows the hypothesis that "FPSE does not Granger cause GDP" is rejected. This, of course, accords with the conventional hypothesis 1 . But in the same table the null hypothesis that "GDP variables do not Granger causes FPSE" is accepted even at four lags. It validates the hypothesis 2. These results, taken together, does not support hypothesis 3 and 4. So a unidirectional relationship between the FPSE and GDP is established. This finding additionally implies that any investigation of the impact of rural poverty on commercial energy consumption should be performed within a simultaneous equation model.

\subsection{Cointegration Test for FMSE, FHSE, FSVE, FASCE, FPCE, FULE and GDP}

The cointegration test for female enrolment variables i.e., FMSE, FHSE, FSVE, FASCE, FPCE and FULE is carried out separately over GDP. Results of regression and ADF test for the residual are presented in Table 6 and Table 7 respectively. The finding reveals that the residual is stationary at level i.e. it is integrated of order zero. This validates the proposition that FMSE, FHSE, FSVE, FASCE, FPCE, FULE and GDP are indeed cointegrated i.e. a long run relationship between them holds. In order to check steadiness of long run relationship between FMSE, FHSE, FSVE, FASCE, FPCE, FULE and GDP, an Error Correction Model (ECM) is applied. The results are presented in Table 8.

The short run effect of GDP on FMSE, FSVE and FPCE is insignificant, while the long run adjustment impact of GDP on FPCE is insignificant. The remaining proxies for short-run effect on GDP is significant i.e., FHSE, FASCE and FULE. While the long-run adjustment impact of GDP on FMSE, FHSE, FSVE, FASCE and FULE is significant with negative value indicating the long run convergence i.e., $3.7 \%, 4.5 \%, 11.8 \%, 26.3 \%$ and $19.2 \%$ respectively would be adjusted in every year. The conclusion is that there is a stable long run relationship between them. 
To confirm the causal relationship between the FMSE-GDP, FHSE-GDP, FSVE-GDP, FASCE-GDP, FPCE-GDP, FULE-GDP, a Granger-Causality test has been applied using lag length up to four periods. The following four hypotheses are tested.

\section{FMSE, FHSE, FSVE, FASCE, FPCE, FULE Granger causes GDP}

2. GDP Grange causes FMSE, FHSE, FSVE, FASCE, FPCE, FULE

3. Causality runs in both directions

4. GDP and FMSE, FHSE, FSVE, FASCE, FPCE, FULE are independent.

The results are provided in Table 9. It shows that the hypothesis that "FMSE does not Granger cause GDP" is rejected. This does accord with the conventional hypothesis 1 . But the null hypothesis that "GDP does not Granger cause to FMSE" is accepted. These results, taken together, does not support hypothesis 3 and 4 and suggest that there is a unidirectional relationship between the FMSE and GDP. The other results shows that FHSE, FSVE, FPCE to GDP and GDP to FHSE, FSVE, FPCE both are independent in nature and support our $4^{\text {th }}$ hypothesis. The final outcome shows that GDP Granger cause FASCE and FULE in one direction, therefore, there has a uni-directional relationship exist. However, FASCE and FULE both do not Granger cause their alternative hypothesis. This supports our $2^{\text {nd }}$ hypothesis.

\section{Conclusion}

The causality approach was used to analyze the relationship between different female enrolment proxies in educational institutions and economic growth over a period of 1966-2008. The short-run effect of female enrolment proxies on GDP is significant i.e., FHSE, FASCE and FULE. While the long-run adjustment impact of GDP on FMSE, FHSE, FSVE, FASCE and FULE is significant with negative value indicating the long run convergence i.e., $3.7 \%, 4.5 \%, 11.8 \%, 26.3 \%$ and $19.2 \%$ respectively, which would be adjusted every year. The conclusion is that there is a stable long run relationship between the female enrolment in educational institutions and economic growth.

The empirical results moderately support the conventional view that GDP has significant long-run casual effect on female enrolment proxies in Pakistan. This present study supports the unidirectional causality relationship between the GDP and female enrolment in the specific context of Pakistan. This also suggests that only single equation method is insufficient to assess the strong relationship. Therefore it is important to establish simultaneous equations for long-run relationship. It is recommended that government should upgrade the priority of education by raising public expenditure on education to at least 4 per cent of GDP, as recommended by UNESCO. This study provides evidence for the Government of Pakistan's focus to female enrolment in educational institutions which can contribute towards the prosperous future of Pakistan.

\section{References}

Abbas, M. (undated). Higher Education in Pakistan; Weaknesses and Remedies. Dean/Director University of Education Lower Mall, Campus Lahore.

Barnet, R. (1990). The Idea of Higher Education. Philadelphia. USA: The Society for Research into Higher Education.

Barro RJ, Lee J-W. (1994). Sources of economic growth. Carnegie-Rochester Conference Series on Public Policy 40:1-46.

Barro RJ, Sala-i-Martin X. (1992). Convergence. Journal of Political Economy, 100:223-251.

Barro RJ. (1991). Economic growth in a cross section of countries. Quarterly Journal of Economics, 106:407-443.

Behrman JR, Deolalikar AB. (1988). Health and nutrition. In: Chenery H, Srinivasan TN (eds), Handbook of development economics, Volume I., North-Holland, Amsterdam.

Bellew R, Raney L, Subbarao K. (1992). Educating girls. Finance and Development, 29:54-56.

Bils M, Klenow PJ. (1998). Does schooling cause growth or the other way around? NBER Working Paper 6393.

Economic Survey of Pakistan. (2009-10). Education and educational facilities. Economic Advisors wing finance division Govt. of Pakistan Islamabad, Pakistan.

Engle, R. F. and C. W. J. Granger. (1987). Cointegration and Error Correction Representation, Estimation and Testing. Econometrica, 55: 251-76.

HDR. (2005). Human development reports (UNDP). Retrieved from hdr.undp.org/reports/global/2005/-14k. 
Hill MA, King EM. (1993). Women's education in developing countries: an overview. In: King EM, Hill MA (eds) Women's education in developing countries: Barriers benefits and policies. Johns Hopkins University Press, Baltimore.

Johansen, S. (1991). Estimation and Hypothesis Testing of Cointegration Vectors in Gaussian Vector Autoregressive Models. Econometrics, 59: 1551-80.

Knowles S, Owen PD. (1995). Health capital and cross-country variation in income per capita in the Mankiw-Romer-Weil model. Economics Letters, 48:99-106.

Knowles S, Owen PD. (1997). Education and health in an effective-labour empirical growth model. Economic Record, 73:314-328.

Lucas RE Jr. (1988). On the mechanics of economic development. Journal of Monetary Economics, 22:3-42.

Mankiw NG, Romer D, Weil DN. (1992). A contribution to the empirics of economic growth. Quarterly Journal of Economics, 107:407-437

MDG. (2006). The Millennium Development Goals Report -2006. United Nations. [Online] Available: http://unstats.un.org/unsd/mdg/Resources/Static/Products/Progress2006/MDGReport2006.pdf.

Ozsoy, C. (2008). The Contribution of Higher Education to Economic Development, 8th Global Conference on Business and Economics, October 18-19, 2008, Florence, Italy.

Philips, P. C. B. and S. Ouliaris. (1990). Asymptotic Properties of Residual Based Tests for Cointegration. Econometrica, 58: 165-93.

Pritchett L. (1996). Where has all the education gone? The World Bank, Policy Research Department, Working Paper a1581.

Romer PM. (1986). Increasing returns and long-run growth. Journal of Political Economy, 94:1002-1037.

Romer PM. (1990). Human capital and growth: theory and evidence. Carnegie-Rochester Conference Series on Public Policy, 32:251-286

SBP. (2005). Annual report of State Bank of Pakistan, 2004-05. [Online] available: http:/www.sbp.org.pk/reports/annual/arfy05/qtr-index-eng.htm.

Schultz TP. (1988). Education investments and returns. In Chenery H, Srinivasan TN (eds) Handbook of development economics, Volume I, North-Holland, Amsterdam.

Schultz TP. (1995). Investments in schooling and health of women and men: quantities and returns.In: Schultz TP (ed.) Investment in women's human capital, University of Chicago Press, Chicago.

Stokey N. (1994). Comments on Barro and Lee. Carnegie-Rochester Conference Series on Public Policy, 40:47-57.

Subbarao K, Raney L. (1995). Social gains from female education: a cross-national study. Economic Development and Cultural Change, 44:105-128.

Wheeler D. (1980). Basic needs fulfillment and economic growth: a simultaneous model. Journal of Development Economics, 7:435-451

World Bank. (2008). The Road Not Traveled Education Reform in the Middle East and North Africa, MENA Development Report, the International Bank for Reconstruction and Development / The World Bank, Washington . 
Table 1. Augmented Dickey-Fuller (ADF) Test on the levels and on the First Difference of the Variables (1980-2007)

\begin{tabular}{|c|c|c|c|c|c|c|}
\hline \multirow[t]{2}{*}{ Variables } & \multirow[t]{2}{*}{ Level } & \multirow[t]{2}{*}{$\begin{array}{c}\text { First } \\
\text { Differences }\end{array}$} & \multicolumn{3}{|c|}{$\begin{array}{c}\text { Mackinnon Critical Values for } \\
\text { Rejection of Hypothesis of a Unit } \\
\text { Root }\end{array}$} & \multirow[t]{2}{*}{ Decision } \\
\hline & & & I \% & $5 \%$ & $10 \%$ & \\
\hline FPSE & 4.298 & -2.145 & -2.622 & -1.949 & -1.611 & $\begin{array}{l}\text { Non Stationary at level but } \\
\text { stationary at first difference i.e., } \\
I(1)\end{array}$ \\
\hline FMSE & 5.221 & -3.934 & -2.622 & -1.949 & -1.611 & $\begin{array}{l}\text { Non Stationary at level but } \\
\text { stationary at first difference i.e., } \\
I(1)\end{array}$ \\
\hline FHSE & 6.758 & -2.863 & -2.622 & -1.949 & -1.611 & $\begin{array}{l}\text { Non Stationary at level but } \\
\text { stationary at first difference i.e., } \\
I(1)\end{array}$ \\
\hline FSVE & 1.273 & -5.440 & -2.622 & -1.949 & -1.611 & $\begin{array}{l}\text { Non Stationary at level but } \\
\text { stationary at first difference i.e., } \\
I(1)\end{array}$ \\
\hline FASCE & 4.002 & -4.872 & -2.622 & -1.949 & -1.611 & $\begin{array}{l}\text { Non Stationary at level but } \\
\text { stationary at first difference i.e., } \\
I(1)\end{array}$ \\
\hline FPCE & 2.209 & -6.498 & -2.622 & -1.949 & -1.611 & $\begin{array}{l}\text { Non Stationary at level but } \\
\text { stationary at first difference i.e., } \\
I(1)\end{array}$ \\
\hline FULE & 4.368 & -1.849 & -2.622 & -1.949 & -1.611 & $\begin{array}{l}\text { Non Stationary at level but } \\
\text { stationary at first difference i.e., } \\
I(1)\end{array}$ \\
\hline GDP & 5.012 & -3.754 & -2.622 & -1.949 & -1.611 & $\begin{array}{l}\text { Non Stationary at level but } \\
\text { stationary at first difference i.e., } \\
I(1)\end{array}$ \\
\hline
\end{tabular}

Note: The null hypothesis is that the series is non-stationary, or contains a unit root. The rejection of the null hypothesis is based on MacKinnon critical values. The lag length are selected based on SIC criteria, this ranges from lag zero to lag one. 
Table 2. Empirical Results of the Model - FPSE (1966-2008)

\begin{tabular}{|l|c|}
\hline Dependent Variable: Log [Female in Primary School Enrolment (FPSE)] \\
\hline Constant & -3.578 \\
& $(-5.563)^{*}$ \\
\hline Log (GDP) & 0.761 \\
& $(4.253)^{*}$ \\
\hline AR(1) & 0.789 \\
& $(5.337)^{*}$ \\
\hline R-squire & 0.974 \\
\hline Adjusted R-squire & 0.973 \\
\hline Durbin-Watson Statistics & 1.874 \\
\hline F-Statistics & 44.216 \\
\hline Probability (F-Statistics) & $0.0000^{*}$ \\
\hline Number of Observations & 43 \\
\hline
\end{tabular}

Note: Values in parentheses show t-statistics. The statistics significant at 1, 5 and $10 \%$ level of significance are indicated by $* * *$ and $* * *$.

Table 3. Augmented Dickey-Fuller Test for the Residuals - FPSE

\begin{tabular}{|c|c|c|c|c|c|c|}
\hline \multirow{2}{*}{$\begin{array}{l}\text { Estimated } \\
\text { Residual } \\
\text { Integratio } \\
\text { n }\end{array}$} & \multirow[t]{2}{*}{ Level } & \multicolumn{3}{|c|}{$\begin{array}{c}\text { Mackinnon Critical Values for } \\
\text { Rejection of Hypothesis of a Unit } \\
\text { Root }\end{array}$} & \multirow[t]{2}{*}{ Decision } & \multirow[t]{2}{*}{$\begin{array}{l}\text { Order of } \\
\text { Integration }\end{array}$} \\
\hline & & $1 \%$ & $5 \%$ & $10 \%$ & & \\
\hline Residual & -2.528 & -2.622 & -1.949 & -1.611 & Stationary at level & I (0) \\
\hline
\end{tabular}

Table 4. Empirical Findings of Error Correction Model - FPSE

\begin{tabular}{|l|c|}
\hline Dependent Variable: DLog (FPSE)] & -2.914 \\
\hline Constant & $(-2.897)^{*}$ \\
\hline Log (GDP) & -0.733 \\
& $(-4.012)^{*}$ \\
\hline$p$ & -0.144 \\
& $(-1.989)^{* * *}$ \\
\hline R-squire & 0.977 \\
\hline Adjusted R-square & 0.975 \\
\hline DW & 1.926 \\
\hline F-Statistics & 55.055 \\
\hline Probability (F-Statistics) & $0.000^{*}$ \\
\hline Number of Observations & 43 \\
\hline
\end{tabular}

Note: Values in parentheses show t-statistics. The statistics significant at 1,5 and $10 \%$ level of significance are indicated by $* * *$ and $* * *$. 
Table 5. Causality Patterns - FPSE

\begin{tabular}{|l|r|c|}
\hline Lagged Years & Null Hypothesis & Decision \\
\hline $\mathbf{1}$ & No causality from Log (FPSE) to Log (GDP) & Rejected \\
& No causality from Log (GDP) to Log (FPSE) & Accepted \\
\hline $\mathbf{2}$ & No causality from Log (FPSE) to Log (GDP) & Rejected \\
& No causality from Log (GDP) to Log (FPSE) & Accepted \\
\hline $\mathbf{3}$ & No causality from Log (FPSE) to Log (GDP) & Accepted \\
& No causality from Log (GDP) to Log & Accepted \\
\hline $\mathbf{4}$ & No causality from Log (FPSE) to Log (GDP) & Accepted \\
& No causality from Log (GDP) to Log (FPSE) & Accepted \\
\hline
\end{tabular}

Table 6. Empirical Results of the Model - FMSE, FHSE, FSVE, FASCE, FPCE, FULE (1966-2008)

\begin{tabular}{|c|c|c|c|c|c|c|}
\hline & Log(FMSE) & Log(FHSE) & Log(FSVE) & Log(FASCE) & Log(FPCE) & Log(FULE) \\
\hline Constant & $\begin{array}{c}-9.150 \\
(-10.571)^{*}\end{array}$ & $\begin{array}{c}-11.770 \\
(-12.376)^{*}\end{array}$ & $\begin{array}{c}-4.378 \\
(-2.004)^{* * *}\end{array}$ & $\begin{array}{c}-8.551 \\
(-13.967)^{*}\end{array}$ & $\begin{array}{c}-25.299 \\
(-10.752)^{*}\end{array}$ & $\begin{array}{c}-21.901 \\
(-10.083)^{*}\end{array}$ \\
\hline Log(GDP) & $\begin{array}{c}0.928 \\
(25.963)^{*}\end{array}$ & $\begin{array}{c}0.995 \\
(25.323)^{*}\end{array}$ & $\begin{array}{c}0.579 \\
(6.406)^{*}\end{array}$ & $\begin{array}{c}0.837 \\
(33.100)^{*}\end{array}$ & $\begin{array}{c}1.464 \\
(15.057)^{*}\end{array}$ & $\begin{array}{c}1.297 \\
(14.450)^{*}\end{array}$ \\
\hline AR(1) & $\begin{array}{c}0.997 \\
(92.411)^{*}\end{array}$ & $\begin{array}{c}0.998 \\
(85.212)^{*}\end{array}$ & $\begin{array}{c}0.995 \\
(19.623)^{*}\end{array}$ & $\begin{array}{c}0.975 \\
(30.474)^{*}\end{array}$ & $\begin{array}{c}0.989 \\
(35.429)^{*}\end{array}$ & $\begin{array}{c}0.747 \\
(5.669)^{*}\end{array}$ \\
\hline R-square & 0.942 & 0.939 & 0.500 & 0.963 & 0.846 & 0.835 \\
\hline $\begin{array}{c}\text { Adjusted } \\
\text { R-Square }\end{array}$ & 0.941 & 0.938 & 0.488 & 0.962 & 0.843 & 0.831 \\
\hline Durbin-Watson & 1.971 & 2.112 & 1.566 & 2.012 & 2.253 & 1.980 \\
\hline $\begin{array}{c}\text { F-statistics } \\
\text { Prob. }\end{array}$ & 674.112 & 641.271 & 41.047 & 1095.623 & 226.711 & 208.182 \\
\hline $\begin{array}{c}\text { (F-statistics) } \\
\text { No. of } \\
\text { Observations }\end{array}$ & 4.000 & 0.000 & 0.000 & 0.000 & 0.000 & 0.000 \\
\hline
\end{tabular}

Note: Values in parentheses show t-statistics. The statistics significant at 1, 5 and $10 \%$ level of significance are indicated by $* * *$ and $* * *$. 
Table 7. Augmented Dickey-Fuller Test for the Residuals - FMSE, FHSE, FSVE, FASCE, FPCE, FULE

\begin{tabular}{|l|c|c|c|c|l|c|}
\hline \multirow{2}{*}{$\begin{array}{l}\text { Estimated } \\
\text { Residual } \\
\text { Integration }\end{array}$} & \multirow{2}{*}{ Level } & \multicolumn{3}{|c|}{$\begin{array}{l}\text { Mackinnon Critical Values for } \\
\text { Rejection of Hypothesis of a } \\
\text { Unit Root }\end{array}$} & \multicolumn{1}{|c|}{ Decision } & Order of \\
Integration & & \\
\cline { 2 - 6 } & & $\mathbf{1} \%$ & $\mathbf{5 \%}$ & $\mathbf{1 0} \%$ & & I $(0)$ \\
\hline FMSE & -2.387 & -2.622 & -1.949 & -1.611 & Stationary at level & I $(0)$ \\
\hline FHSE & -1.985 & -2.622 & -1.949 & -1.611 & Stationary at level & I $(0)$ \\
\hline FSVE & -1.629 & -2.622 & -1.949 & -1.611 & Stationary at level & I $(0)$ \\
\hline FASCE & -2.936 & -2.622 & -1.949 & -1.611 & Stationary at level & I $(0)$ \\
\hline FPCE & -1.941 & -2.622 & -1.949 & -1.611 & Stationary at level & I $(0)$ \\
\hline FULE & -1.645 & -2.622 & -1.949 & -1.611 & Stationary at level & \\
\hline
\end{tabular}

Table 8. Empirical Findings of Error Correction Model - FMSE, FHSE, FSVE, FASCE, FPCE, FULE (1966-2008)

\begin{tabular}{|c|c|c|c|c|c|c|}
\hline & DLog(FMSE) & DLog(FHSE) & DLog(FSVE) & DLog(FASCE) & DLog(FPCE) & DLog(FULE) \\
\hline Constant & $\begin{array}{c}0.068 \\
(5.830)^{*}\end{array}$ & $\begin{array}{c}0.074 \\
(5.597)^{*}\end{array}$ & $\begin{array}{c}0.089 \\
(1.589)\end{array}$ & $\begin{array}{c}0.043 \\
(2.345)^{* *}\end{array}$ & $\begin{array}{c}0.113 \\
(2.179)^{* *}\end{array}$ & $\begin{array}{c}0.088 \\
(1.348)\end{array}$ \\
\hline DLog(GDP) & $\begin{array}{c}-0.034 \\
(-0.387)\end{array}$ & $\begin{array}{c}0.021 \\
(1.889)^{* * *}\end{array}$ & $\begin{array}{c}-0.278 \\
(-0.662)\end{array}$ & $\begin{array}{c}0.324 \\
(2.344)^{* *}\end{array}$ & $\begin{array}{c}-0.101 \\
(-0.263)\end{array}$ & $\begin{array}{c}0.195 \\
(1.921)^{* * *}\end{array}$ \\
\hline$p$ & -0.037 & -0.045 & -0.118 & -0.263 & -0.110 & -0.192 \\
$(-1.928)^{* * *}$ & $(-2.012)^{* * *}$ & $(-3.895)^{*}$ & $(-2.526)^{* *}$ & $(-1.625)$ & $(-1.770)^{* * *}$ \\
\hline R-square & 0.561 & 0.498 & 0.345 & 0.202 & 0.158 & 0.421 \\
\hline $\begin{array}{c}\text { Adjusted } \\
\text { R-Square }\end{array}$ & 0.552 & 0.497 & 0.343 & 0.161 & 0.121 & 0.401 \\
\hline Durbin-Watson & 1.652 & 1.742 & 1.452 & 1.866 & 2.145 & 2.055 \\
\hline F-statistics & 2.923 & 4.213 & 3.121 & 4.957 & 1.290 & 5.012 \\
\hline $\begin{array}{c}\text { Prob. } \\
\text { (F-statistics) }\end{array}$ & 0.045 & 0.021 & 0.025 & 0.012 & 0.309 & 0.002 \\
\hline $\begin{array}{c}\text { No. of } \\
\text { Observations }\end{array}$ & 43 & 43 & 43 & 43 & 43 & 43 \\
\hline No: Valn & & & & & & \\
\hline
\end{tabular}

Note: Values in parentheses show t-statistics. The statistics significant at 1,5 and $10 \%$ level of significance are indicated by *, ** and ***. 
Table 9. Causality Patterns - FMSE, FHSE, FSVE, FASCE, FPCE, FULE

\begin{tabular}{|c|c|c|}
\hline Lagged Years & $\begin{array}{r}\text { Null Hypothesis } \\
\text { FMSE }\end{array}$ & Decision \\
\hline 1 & $\begin{array}{l}\text { No causality from } \log (\mathrm{FMSE}) \text { to } \log (\mathrm{GDP}) \\
\text { No causality from } \log (\mathrm{GDP}) \text { to } \log (\mathrm{FMSE})\end{array}$ & $\begin{array}{l}\text { Rejected } \\
\text { Accepted }\end{array}$ \\
\hline 2 & $\begin{array}{l}\text { No causality from Log (FMSE) to Log (GDP) } \\
\text { No causality from Log (GDP) to Log (FMSE) }\end{array}$ & $\begin{array}{l}\text { Accepted } \\
\text { Accepted }\end{array}$ \\
\hline 3 & $\begin{array}{l}\text { No causality from Log (FMSE) to Log (GDP) } \\
\text { No causality from Log (GDP) to Log (FMSE) }\end{array}$ & $\begin{array}{l}\text { Accepted } \\
\text { Accepted }\end{array}$ \\
\hline 4 & $\begin{array}{l}\text { No causality from Log (FMSE) to Log (GDP) } \\
\text { No causality from Log (GDP) to Log (FMSE) }\end{array}$ & $\begin{array}{l}\text { Accepted } \\
\text { Accepted }\end{array}$ \\
\hline \multicolumn{3}{|c|}{ FHSE } \\
\hline 1 & $\begin{array}{l}\text { No causality from } \log (\mathrm{FHSE}) \text { to } \log (\mathrm{GDP}) \\
\text { No causality from } \log (\mathrm{GDP}) \text { to } \log (\mathrm{FHSE})\end{array}$ & $\begin{array}{l}\text { Accepted } \\
\text { Accepted }\end{array}$ \\
\hline 2 & $\begin{array}{l}\text { No causality from Log (FHSE) to Log (GDP) } \\
\text { No causality from Log (GDP) to Log (FHSE) }\end{array}$ & $\begin{array}{l}\text { Accepted } \\
\text { Accepted }\end{array}$ \\
\hline 3 & $\begin{array}{l}\text { No causality from Log (FHSE) to Log (GDP) } \\
\text { No causality from Log (GDP) to Log (FHSE) }\end{array}$ & $\begin{array}{l}\text { Accepted } \\
\text { Accepted }\end{array}$ \\
\hline 4 & $\begin{array}{l}\text { No causality from } \log \text { (FHSE) to } \log (\mathrm{GDP}) \\
\text { No causality from } \log (\mathrm{GDP}) \text { to } \log (\mathrm{FHSE})\end{array}$ & $\begin{array}{l}\text { Accepted } \\
\text { Accepted }\end{array}$ \\
\hline \multicolumn{3}{|c|}{ FSVE } \\
\hline 1 & $\begin{array}{l}\text { No causality from } \log \text { (FSVE) to } \log (\mathrm{GDP}) \\
\text { No causality from } \log (\mathrm{GDP}) \text { to } \log (\mathrm{FSVE})\end{array}$ & $\begin{array}{l}\text { Accepted } \\
\text { Accepted }\end{array}$ \\
\hline 2 & $\begin{array}{l}\text { No causality from } \log \text { (FSVE) to } \log (\mathrm{GDP}) \\
\text { No causality from } \log (\mathrm{GDP}) \text { to } \log (\mathrm{FSVE})\end{array}$ & $\begin{array}{l}\text { Accepted } \\
\text { Accepted }\end{array}$ \\
\hline 3 & $\begin{array}{l}\text { No causality from Log (FSVE) to Log (GDP) } \\
\text { No causality from Log (GDP) to Log (FSVE) }\end{array}$ & $\begin{array}{l}\text { Accepted } \\
\text { Accepted }\end{array}$ \\
\hline 4 & $\begin{array}{l}\text { No causality from Log (FSVE) to Log (GDP) } \\
\text { No causality from Log (GDP) to Log (FSVE) }\end{array}$ & $\begin{array}{l}\text { Accepted } \\
\text { Accepted }\end{array}$ \\
\hline \multicolumn{3}{|c|}{ FASCE } \\
\hline 1 & $\begin{array}{l}\text { No causality from } \log \text { (FASCE) to } \log \text { (GDP) } \\
\text { No causality from } \log \text { (GDP) to } \log \text { (FASCE) }\end{array}$ & $\begin{array}{l}\text { Accepted } \\
\text { Rejected }\end{array}$ \\
\hline 2 & $\begin{array}{l}\text { No causality from } \log \text { (FASCE) to } \log \text { (GDP) } \\
\text { No causality from } \log \text { (GDP) to } \log \text { (FASCE) }\end{array}$ & $\begin{array}{l}\text { Accepted } \\
\text { Accepted }\end{array}$ \\
\hline 3 & $\begin{array}{l}\text { No causality from } \log \text { (FASCE) to } \log \text { (GDP) } \\
\text { No causality from } \log \text { (GDP) to } \log \text { (FASCE) }\end{array}$ & $\begin{array}{l}\text { Accepted } \\
\text { Accepted }\end{array}$ \\
\hline 4 & $\begin{array}{l}\text { No causality from } \log \text { (FASCE) to } \log \text { (GDP) } \\
\text { No causality from } \log \text { (GDP) to } \log \text { (FASCE) }\end{array}$ & $\begin{array}{l}\text { Accepted } \\
\text { Accepted }\end{array}$ \\
\hline \multicolumn{3}{|c|}{ FPCE } \\
\hline 1 & $\begin{array}{l}\text { No causality from } \log (\text { FPCE) to } \log (\mathrm{GDP}) \\
\text { No causality from } \log (\text { GDP) to } \log (\text { FPCE) }\end{array}$ & $\begin{array}{l}\text { Accepted } \\
\text { Accepted }\end{array}$ \\
\hline 2 & $\begin{array}{l}\text { No causality from } \log \text { (FPCE) to } \log (\mathrm{GDP}) \\
\text { No causality from } \log (\mathrm{GDP}) \text { to } \log (\mathrm{FPCE})\end{array}$ & $\begin{array}{l}\text { Accepted } \\
\text { Accepted }\end{array}$ \\
\hline 3 & $\begin{array}{l}\text { No causality from } \log \text { (FPCE) to } \log (\mathrm{GDP}) \\
\text { No causality from } \log (\mathrm{GDP}) \text { to } \log (\mathrm{FPCE})\end{array}$ & $\begin{array}{l}\text { Accepted } \\
\text { Accepted }\end{array}$ \\
\hline 4 & $\begin{array}{l}\text { No causality from } \log (\text { FPCE) to } \log (\mathrm{GDP}) \\
\text { No causality from } \log (\mathrm{GDP}) \text { to } \log (\mathrm{FPCE})\end{array}$ & $\begin{array}{l}\text { Accepted } \\
\text { Accepted }\end{array}$ \\
\hline \multicolumn{3}{|c|}{ FULE } \\
\hline 1 & $\begin{array}{l}\text { No causality from Log (FULE) to Log (GDP) } \\
\text { No causality from Log (GDP) to Log (FULE) }\end{array}$ & $\begin{array}{l}\text { Accepted } \\
\text { Rejected }\end{array}$ \\
\hline 2 & $\begin{array}{l}\text { No causality from Log (FULE) to Log (GDP) } \\
\text { No causality from Log (GDP) to Log (FULE) }\end{array}$ & $\begin{array}{l}\text { Accepted } \\
\text { Accepted }\end{array}$ \\
\hline 3 & $\begin{array}{l}\text { No causality from Log (FULE) to } \log \text { (GDP) } \\
\text { No causality from } \log \text { (GDP) to Log (FULE) }\end{array}$ & $\begin{array}{l}\text { Accepted } \\
\text { Accepted }\end{array}$ \\
\hline 4 & $\begin{array}{l}\text { No causality from Log (FULE) to Log (GDP) } \\
\text { No causality from Log (GDP) to Log (FULE) }\end{array}$ & $\begin{array}{l}\text { Accepted } \\
\text { Accepted }\end{array}$ \\
\hline
\end{tabular}



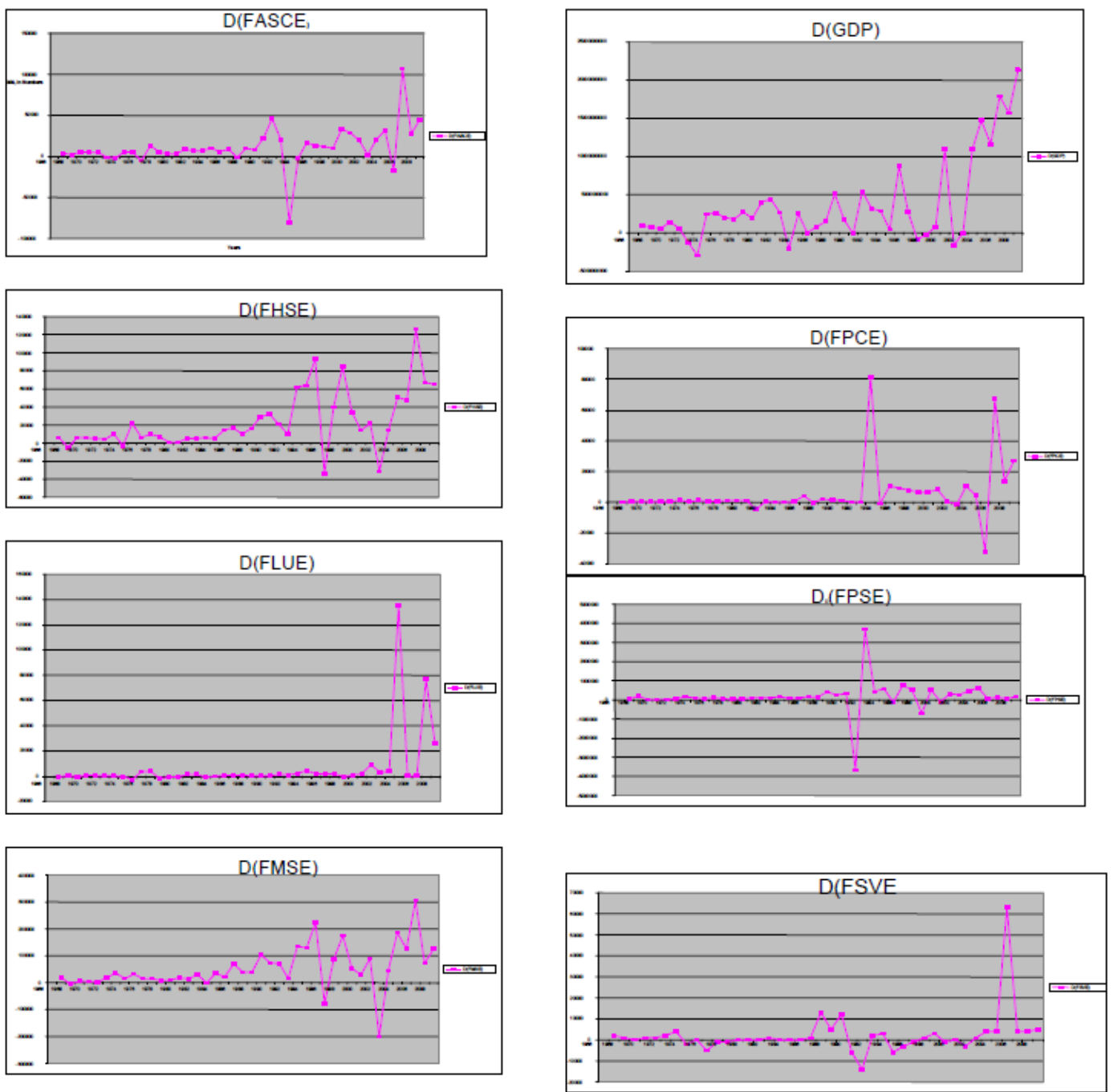

Figure 1. Trends of Variables with First Differences 